\title{
Primary Extrarenal Renal Cell Carcinoma: A Unique Diagnosis Performed through Endoscopic Ultrasound
}

\author{
Gonçalo Nunes $^{a}$ Pedro Pinto-Marques ${ }^{a, b}$ Pedro Sequeira ${ }^{c}$ \\ Evelina Mendonçad $^{d}$ \\ ${ }^{a}$ Gastroenterology Department, Hospital Garcia de Orta, Almada, Portugal; b Gastroenterology Department, \\ Hospital da Luz, Lisbon, Portugal; ' Pathology Department, Hospital Garcia de Orta, Almada, Portugal; \\ dPathology Department, Hospital da Luz, Lisbon, Portugal
}

\section{Keywords}

Endoscopic ultrasound · Adrenal tumour · Extrarenal renal cell carcinoma

\section{Carcinoma de células renais extrarrenal primário: um} diagnóstico único realizado por ecoendoscopia

\section{Palavras Chave}

Ecoendoscopia - Tumor da suprarrenal · Carcinoma de células renais extrarrenal

Renal cell carcinoma (RCC) is the most common kidney cancer in adults, accounting for more than $90 \%$ of renal neoplasms. Clear cell carcinoma is the most prevalent histologic subtype followed by papillary RCC. They are thought to be derived from nephron proximal tubules [1].

Endoscopic ultrasound with fine-needle aspiration (EUS-FNA) plays a major role in the diagnosis and staging of gastrointestinal malignancies. It also proved to be effective in assessing and sampling both adrenal glands [2].

\section{KARGER}

E-Mail karger@karger.com www.karger.com/pjg
(C) 2019 Sociedade Portuguesa de Gastrenterologia Published by S. Karger AG, Basel

Karger

Open access

This article is licensed under the Creative Commons AttributionNonCommercial-NoDerivatives 4.0 International License (CC BYNC-ND) (http://www.karger.com/Services/OpenAccessLicense) Usage and distribution for commercial purposes as well as any distribution of modified material requires written permission.
A 62-year-old asymptomatic male underwent a routine abdominal ultrasound which was unremarkable except for a $9-\mathrm{cm}$ right adrenal mass. No additional lesions were seen on computed tomography (CT) and a laparoscopic right adrenalectomy was performed. Surgical pathology revealed a well-delimited tumour with bleeding and necrotic areas. It was composed by papilla coated by cells with nuclear pseudostratification, rounded nucleus with irregular nuclear membrane, prominent nucleolus, and eosinophilic cytoplasm. Surgical margins were tumour free and the remaining adrenal parenchyma was normal. Immunohistochemistry (IHC) was positive for RCC Ma, CK7, CD10, and racemase, being negative for CK20, CD117, and all adrenal cortex markers (MelanA, calretinin, inhibin, synaptophysin, and chromogranin A). Although these findings were suggestive of metastatic papillary RCC, both kidneys were normal in the abdominal MRI. Of note, whole body positron emission tomography (PET-CT) was negative.

One year later, a new left adrenal nodule was detected on a surveillance CT. The patient was referred for EUS, which revealed a well-delimited isoechoic nodule with a diameter of $24 \mathrm{~mm}$ and a $3-\mathrm{mm}$ cystic area inside. The lesion was punctured with a 22-gauge needle (Fig. 1). Cell 

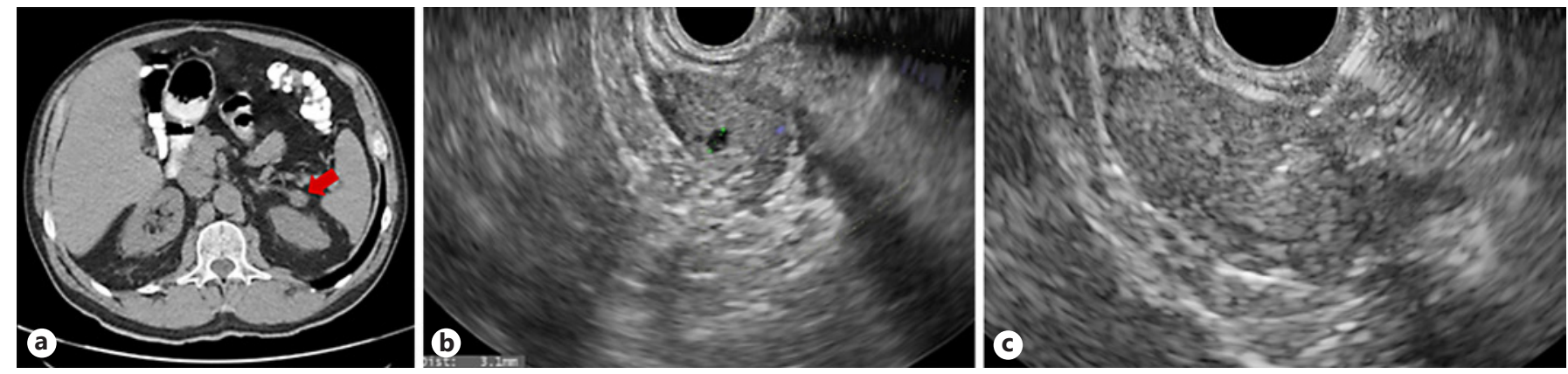

Fig. 1. Abdomen CT scan (a): left adrenal nodule observed on a surveillance CT performed after 1 year of right adrenalectomy; both kidneys were normal, without nodular lesions. Endoscopic ultrasound: the same nodule with a diameter of $24 \mathrm{~mm}$ and a 3-mm cystic area inside (b). Puncture using a 22-gauge needle (c).
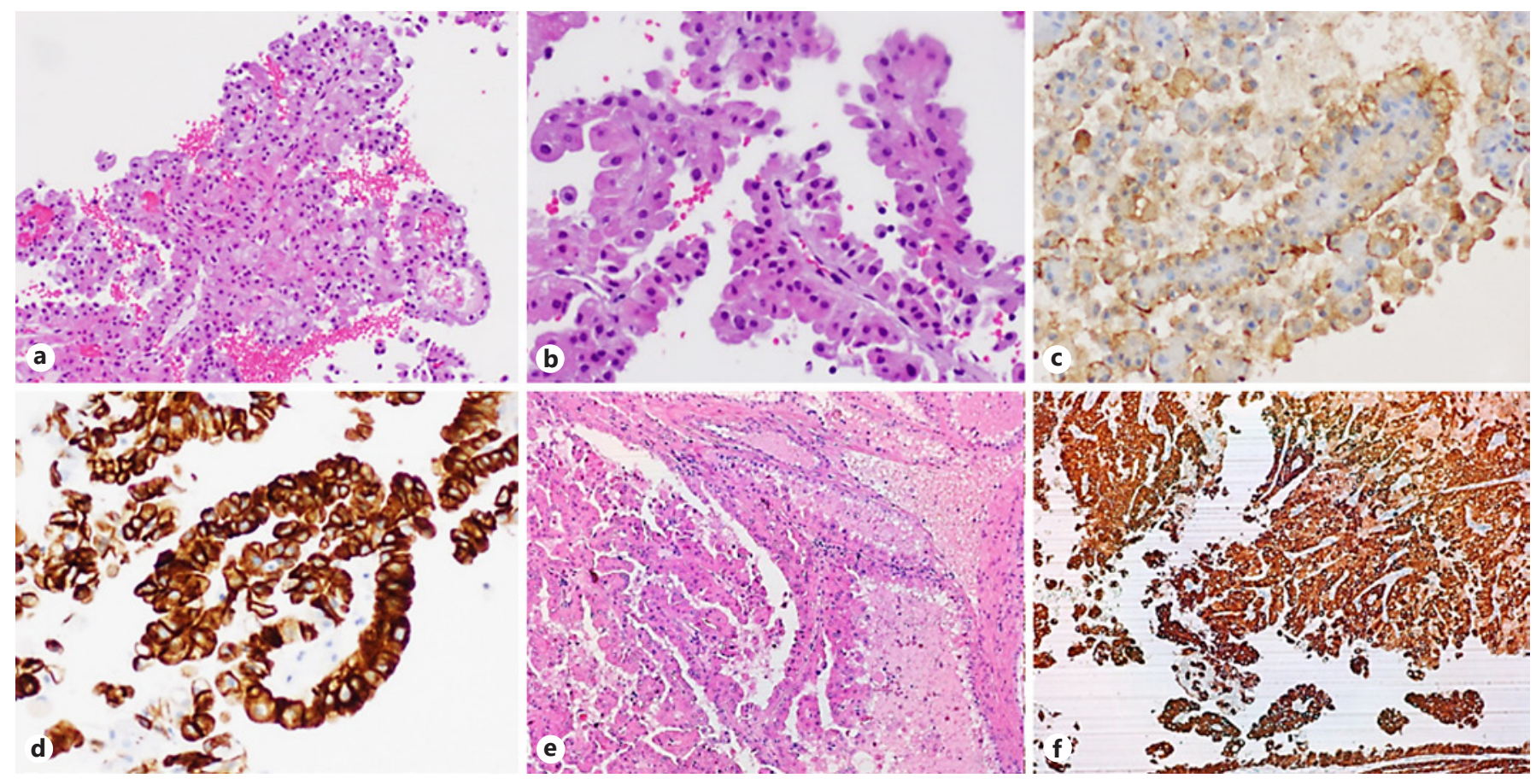

Fig. 2. Adrenal cellblock from EUS-FNA (a, b haematoxylin and eosin; c renal cell carcinoma marker; d cytokeratin 7). Surgical pathology of the left adrenal gland (e haematoxylin and eosin; $\mathbf{f}$ racemase). Both specimens presented the same IHC phenotype.

block was consistent with RCC and the IHC was similar to the previous tumour. Surgical pathology after left adrenalectomy confirmed the diagnosis of papillary RCC (Fig. 2). After 6 months, the patient remained in oncologic remission and no additional lesions were detected.

Extrarenal RCC is defined as the occurrence of RCC in locations other than the normal native kidneys [3]. During fetal kidney development, pronephros, mesonephros, and metanephros emerge, but only metanephros persists and gives rise to metanephric blastemal, which lead to the normal postnatal kidneys. Remarkably, the kidneys and the adrenal cortex share a common ancestor, the intermediate mesoderm. Some authors speculate that despite this differentiation observed during gestation, some mesonephric structures may persist in postnatal life. These mesodermal cells of renal lineage, when located in the adrenal gland ectopic environment, may become predisposed for cancer transformation [4]. Although previously de- 
scribed in patients with supernumerary kidneys, extrarenal RCC is an extremely rare condition, with only two reported cases in patients with normal bilateral kidneys: one located in perirenal fat tissue and another one in the left adrenal gland. In both cases, diagnosis was suspected by radiologic imaging, being further confirmed after surgical resection [3-5].

We report the first case of extrarenal RCC with metachronous involvement of both adrenal glands. To the best of our knowledge, the use of EUS-FNA for preoperative diagnosis of extrarenal RCC had never been accomplished. The exact origin of these neoplasms and its biological behaviour and natural history need to be clarified to optimise patient management and follow-up.

\section{Statement of Ethics}

All procedures performed were in accordance with the ethical standards of the institutional and/or national research committee.

\section{Disclosure Statement}

There are no financial or other conflicts of interest regarding this article. The manuscript content was not presented anywhere else.

\section{References}

1 Hsieh JJ, Purdue MP, Signoretti S, Swanton C, Albiges L, Schmidinger M, et al. Renal cell carcinoma. Nat Rev Dis Primers. 2017 Mar;3: 17009.

2 Stelow EB, Debol SM, Stanley MW, Mallery S, Lai R, Bardales RH. Sampling of the adrenal glands by endoscopic ultrasound-guided fine-needle aspiration. Diagn Cytopathol. 2005 Jul;33(1):26-30.

3 Hasan R, Kumar S, Monappa V, Ayachit A. Primary extra-renal clear cell renal cell carci- noma masquerading as an adrenal mass: A diagnostic challenge. Urol Ann. 2015 Oct-Dec: 7(4):513-5.

4 Terada T. Extra-renal clear cell renal cell carcinoma probably arising from mesodermal embryonic remnants. Pathol Int. 2012 Apr; 62(4):291-3.

5 Chawla A, Rao M, Ithawala M, Philipraj J, Sasidharan K. Synchronous renal cell carcinoma in supernumerary and ipsilateral kidneys. BJU Int. 2002;90:e11. 